\title{
Paisajes sociales: la visibilidad en la construcción de identidades
}

Félix de la Iglesia Salgado, arquitecto

\section{Entornos, objetos, sujetos...}

Abandonamos la ruta de la Plata para adentrarnos en el parque natural Sierra de Aracena y Picos de Aroche por la antigua senda de los contrabandistas, voz que nos anuncia tierras de fronteras y conflictos de ida y vuelta, que nos acerca a situaciones límites. Camino a la ciudad de Cala, dejamos al paso el castillo de Santa Olalla del Cala, campanarios y cigüeñas, alineaciones de árboles que atraviesan dehesas de encinas y alcornoques, piaras de cochinos... hasta llegar a las primeras construcciones de su caserío que se pliegan al camino recibiendo al visitante. Ya en el centro, al girar la carretera a la derecha, surge en lo alto de un cerro la imagen de la fortaleza recortada entre los árboles, con su silencio elocuente y mirada pregnante.

"Y vio entonces allá arriba el castillo; vio en el aire claro su nítido contorno, más nítidamente perfilado aún por la nieve que, extendida en fina capa por doquier, reproducia todas las formas (...) En conjunto, tal y como se mostraba allá a lo lejos, respondía el castillo a la expectativa de K. No era ni un antiguo burgo feudal, ni un suntuoso palacio nuevo, sino una planta extensa..." (Franz Kafka. El Castillo)

El castillo, con una clara volumetría perfilada en su coronación con limpias líneas que lo hacen fácilmente reconocible, se incorpora con su presencia a un imaginario que nos resulta familiar. No cabe duda de que con él se establece una relación cultural, una mediación entre el ser humano y su entorno, que nos permite identificarnos con estos lugares singulares.

Al detenernos, esa relación se intensifica o hace más directa: se acrecienta la inquietud por un mayor conocimiento y comprensión de lo que esta pieza significa, al tiempo que se hace necesaria la experiencia fisica de la misma. Ahora bien, en primer lugar, es obvio que no nos relacionamos con el objeto original, no hay tal, a lo más un cuasiobjeto -recordemos a Michel Serres o Bruno Latour- móvil en el tiempo, fluctuante, híbrido; $y$, además, aquel mundo en el que el objeto como referente tenía sentido se ha descompuesto con infinidad de registros e informaciones, de impulsos y sensaciones... en mil fragmentos inimaginables e imposibles de recomponer. $Y$ ahi está y aqui estamos, conscientes de que su imagen gravita tanto sobre la vida de los caliches -o caleños- como del visitante ocasional. Para ello, entre su nada lejano estado de abandono y ruina y el momento actual, parece claro que ha sido necesario producir la intermediación entre los numerosos elementos encontrados, entre las distintas escalas de aproximación al mismo, entre el paisaje y la materialidad... lo que ha requerido de un sentido, de una propuesta patrimonial que se estableciera en guia de orientación de futuros comportamientos en el medio o en discurso vehicular de enganche al bien protegido.

En esta dimensión se sitúa el valor de la intervención que nos presenta republica_dm, una acción patrimonial rigurosa, precisa y significativa donde las categorias para su comprensión deben ser otras -las que atienden al azar o al dilatado proceso participado en el tiempo, entre otrasy las lecturas -los significados que proyecta la nueva imagen en el mundo de afuera, de la sociabilidad, del patrimonio, etc-. se singularizan y potencian. No se trata ya de hablar de lo verdadero o falso, de lo natural o artificial, de sujetos u objetos, de teoria o aplicación práctica: las dicotomias se funden en la experiencia de la nueva situación. Se trata de programar un instrumento, como nos dice Vilém Flusser en Texto e imagen (2001), "dirigido hacia el entorno para informarlo y convertirlo en cultura, en situación humana (...) Los seres humanos ya no se orientan en su entorno con la ayuda de imágenes, sino que se orientan en la imagen mediante el entorno".

\section{Los conceptos que se programaron para} hacerlo imaginable. Cuestión de miradas

Nos situamos, pues, ante su imagen, lo que -como nos ha revelado Didi-Huberman- no es otra cosa que estar ante el tiempo, "una imagen que no es ni la ilusión pura, ni toda la verdad, sino ese latido dialéctico que agita, al mismo tiempo, el velo y su jirón" (2004).

La intervención responde a un largo proceso transdisciplinar de aproximaciones y toma de decisiones colegiadas por quienes han participado en ella; algo que se traduce en un conocimiento exhaustivo de la fortaleza en la perspectiva de abrirla a nuevas interpretaciones. Referenciadas las acciones de manera explicita en los criterios marcados en la Carta de Cracovia 2000, habria que destacar la valoración arquitectónica y paisajística como patrimonio cultural, así como la participación de los ciudadanos en el proceso, lo que ha favorecido la socialización del bien y entorno.

Será la recuperación de la mirada abierta y lejana, tanto del castillo como desde el castillo, uno de los presupuestos de partida. Que la pieza recomponga su volumetria ofreciéndose a la ciudad con sus tres lienzos murarios restituidos y en la cara noreste, virtualmente, recupere el camino de ronda sobre los restos encontrados, posibilitando una intencionada mirada y valoración del paisaje de la dehesa, dan cuenta de ello. Y será en esta cara oculta, recuerdo del Promontorio del sueño de Victor Hugo, donde aparezca la sorpresa: algo se posa en la vieja ruina ahora estabilizada, un ligero animal - ¿una bicha?- a punto de saltar y abandonar, como nos diría aquella Coop Himmelblau de las primeras obras, este nuevo suelo histórico reconfigurado. Es el contraste a la "perfecta conjunción" de lo nuevo con lo viejo. Se complementa la visión.

Con otro registro distinto, a medida que nos acercamos a la obra, la disposición y superposición de planos -consolidados, recuperados, reinventados- descomponen la apariencia de aquella imagen para enfrentarse con la materialidad de la obra, con sus diferentes texturas, colores, formatos y reflejos. Ello nos conduce al tacto -ahora soporte de la mirada- y a establecer con el recinto una experiencia más directa y personal.

Así, el castillo se convierte en un dispositivo de comprensión y activación del territorio. Los itinerarios -iniciáticos- de acceso a la fortaleza son una invitación a la participación del paisaje; el recinto interior es plataforma disponible para el encuentro a la vez que valoración de su suelo natural y de la posición relativa en el cerro; los lienzos -restituidos o reinterpretados- de la muralla serán soportes de recorridos y ventanas que capturan y traen el mundo de afuera al interior en una experiencia única; su materialidad se traduce en sensaciones, en mirada y tacto; lo visible y lo que, oculto, se desvela, lo íntimo y lo externo, lo menudo y lo extenso se consideran componentes de un escenario para la vida. Algo de lo que Didi-Huberman, en Ser cráneo, ve en las esculturas y escritos de Giuseppe Penone: una arquitectura de efectos que pone en relación presencias y ausencias a través de la experiencia y que, con esos argumentos, da encarnadura a espacios olvidados, haciéndolos visibles.

Si la acción patrimonial transita del pensamiento imaginativo al conceptual y viceversa, este modelo de intervención en el castillo de Cala supone una entrada renovada en este mundo, dando cuenta de los acontecimientos de la memoria, reinventando la relación sujetoartefacto-ambiente y constituyéndose como esfera participativa y provisional.

\section{Bibliografía}

FLUSSER, V. (2001) Texto e imagen. En Una filosofia de la fotografia. Madrid: Sintesis, 2001

DIDI-HUBERMAN, G. (2004) Imágenes pese a todo. Barcelona: Paidós, 2004 